\section{Notaike}

Vol. 3 No. 3, Oktober 2020
e-ISSN: 2655-9404

p-ISSN: 2721-8376

DOI: $10.20473 /$ ntr.v3i3.22831

Article history: Submitted 20 August 2020; Accepted 2 September 2020; Available online 1 October 2020.

\title{
Perolehan Hak Milik yang Berasal Dari Perjanjian Pengikatan Jual Beli (PPJB) Terhadap Bangunan yang Berdiri Di Atas Tanah Negara Bekas Hak Eigendom
}

\author{
Diyah Retno Habiba \\ diyahretnoh@gmail.com \\ Universitas Airlangga
}

\begin{abstract}
Before the Basic Agrarian Law was introduced, the law of the land system in Indonesia still adheres to customary law and western law. One of them is the eigendom rights, which after the Basic Agrarian Law was put into practice, this eigendom rights practice was also put to an end and it must be converted by the Basic Conversion Provisions of the Agrarian Law. The method used in this research is the normative method through a statute approach and conceptual approach. In this research, it is known that the sale and purchase of land to inflict legal actions of transfer of rights which adhere to the principle of cash, reality, and clarity. Also, there are legal requirements for sale and purchase that must be met to obtain a sale deed as written evidence that is an authentic deed. Regarding the procedure for obtaining ownership of state land, it is already stated in the Regulation of the Minister of Agrarian Affairs/Head of the National Land Agency Number 9 of 1999 concerning Procedures for Granting and Canceling State Land Rights and Management Rights which are submitted in writing to the Minister through the Regency/City National Land Agency.

Keywords: Eigendom; Conversion; Land Purchase; Rights and Authorities of Building Owners; Procedure for Acquisition of Proprietary Rights over State Land.
\end{abstract}

\footnotetext{
Abstrak

Sebelum berlakunya Undang-Undang Pokok Agraria, sistem pertanahan di Indonesia masih menganut pada hukum adat dan hukum barat. Salah satunya hak eigendom yang setelah berlakunya Undang-Undang Pokok Agraria, hak eigendom ini sudah tidak berlaku lagi dan harus dikonversi sesuai dengan Ketentuan Konversi Undang-Undang Pokok Agraria. Metode penelitian yang digunakan yaitu metode normatif dengan melalui pendekatan undang-undang dan pendekatan konseptual. Dalam penelitian ini, diketahui bahwa jual beli tanah menimbulkan perbuatan hukum pemindahan hak yang menganut asas tunai, riil dan terang. Selain itu, terdapat syarat sahnya jual beli yang harus dipenuhi guna menghasilkan akta jual beli sebagai alat bukti tertulis yang bersifat akta otentik. Mengenai prosedur perolehan hak milik atas tanah negara sudah tercantum dalam Peraturan Menteri Negara Agraria/Kepala Badan Pertanahan Nasional Nomor 9 Tahun 1999 tentang Tata Cara Pemberian dan Pembatalan Hak Atas Tanah Negara dan Hak Pengelolaan yang diajukan secara tertulis kepada Menteri melalui Badan Pertanahan Nasional Kabupaten/Kota.

Kata Kunci: Hak Eigendom; Konversi; Jual Beli Tanah; Hak dan Wewenang Pemilik Bangunan; Tata Cara Perolehan Hak Milik Atas Tanah Negara.
} 


\section{Pendahuluan}

Tanah merupakan kebutuhan primer bagi manusia yang secara konstitusional digunakan dan dikuasai negara demi terjaminnya kemakmuran rakyat sebagaimana yang tercantum dalam Pasal 33 ayat (3) UUD 1945 dan Pasal 2 ayat (1) Undang-Undang Nomor 5 Tahun 1960 tentang Peraturan Dasar PokokPokok Agraria. Dalam arti yuridis, tanah merupakan permukaan bumi yang telah dibatasi secara resmi oleh Undang-Undang Pokok Agraria. ${ }^{1}$ Permukaan bumi yang dimaksud dalam hal ini bukan mengatur dalam segala aspeknya, melainkan hanya mengatur salah satunya saja yang disebut sebagai hak. ${ }^{2}$ Secara umum, tanah merupakan suatu permukaan atau lapisan bumi yang letaknya berada pada bagian atas sendiri. Sedangkan menurut A.P. Parlindungan, tanah merupakan salah satu bagian dari bumi sebagaimana yang telah tercantum dalam Pasal 4 ayat (1) Undang-Undang Pokok Agraria.

Undang-Undang Pokok Agraria sudah sangat jelas mengatur mengenai tanah beserta kepastian hukumnya. Misalnya saja dalam Pasal 4 ayat (2) UndangUndang Pokok Agraria yang mengatur mengenai hak-hak atas tanah dengan memberikan wewenang untuk mempergunakan tanah dengan batasan-batasan yang telah dimuat dalam Undang-Undang Pokok Agraria dan peraturan lain yang lebih tinggi dimana dalam hal ini kekuasaan negara sangat mendominasi atas tanah yang haknya tidak dipunyai seseorang. Tujuannya agar negara dapat memberikan tanah yang haknya tidak dipunyai seseorang atau badan hukum dengan suatu hak menurut peruntukannya dan keperluannya. Sebagai bentuk kepastian hukum atas bidang tanah yang dimilikinya, terdapat bukti kepemilikan yang mana dengan adanya kepastian hukum atas bidang tanah ini mencakup tiga hal yaitu kepastian hukum mengenai objek hak atas tanah, subyek hak atas tanah dan status hak atas tanah. ${ }^{3}$ Salah satu dari hak atas tanah yang dimaksud dalam

\footnotetext{
1 Boedi Harsono, Hukum Agraria Indonesia: Sejarah Pembentukan Undang-Undang Pokok Agraria, Isi Dan Pelaksanaannya (Djambatan 2008).[18].

2 Urip Santoso, Hukum Agraria: Kajian Komprehensif (Kencana 2012).[9].

3 Andhi Mahligai, 'Penerapan Alternatif Penyelesaian Sengketa Dan Konflik Pertanahan Melalui Mediasi Untuk Mewujudkan Kepastian Hukum Di Bidang Pertanahan Nasional Republik Indonesia' (Universitas Atma Jaya Yogyakarta 2013).[34].
} 
Pasal 16 ayat (1) Undang-Undang Pokok Agraria adalah hak milik yang tercantum dalam Pasal 20 Undang-Undang Pokok Agraria yang merupakan suatu hak atas tanah secara turun-temurun, terkuat dan terpenuh yang dapat dipunyai oleh seseorang dengan mengingat ketentuan dalam Pasal 6 Undang-Undang Pokok Agraria serta tidak terdapat jangka waktu penguasaan atas tanahnya baik untuk diusahakan maupun untuk suatu bangunan.

Dengan adanya bukti kepemilikan yang merupakan bentuk dari kepastian hukum dan mempunyai kekuatan hukum tetap dimana dalam Pasal 19 ayat (1) Undang-Undang Pokok Agrarai sudah menjamin kepastia hukum yang diberikan oleh pemerintah dengan dilakukannya kegiatan pendaftaran tanah sebagaimana yang tercantum dalam Pasal 1 angka 1 Peraturan Pemerintah Nomor 24 Tahun 1997 tentang Pendaftaran Tanah dimana dengan adanya pendaftaran tanah ini nantinya akan menghasilkan sertipikat yang mempunyai kepastian hukum yang tetap guna untuk meminimalisir jika nantinya terjadi suatu sengketa, konflik dan perkara. Selain itu, pendaftaran tanah ini merupakan suatu kegiatan yang sangat penting dalam membangun dan mewujudkan kepastian hukum serta penataan kembali penggunaan, penguasaan dan pemilikan hak atas tanah. Apalagi jika tanahnya masih tunduk pada hukum barat seperti hak eigendom, maka pendaftaran tanah ini sangat penting dengan tujuan untuk memberikan kepastian hukum serta adanya tanda bukti kepemilikan hak berupa sertipikat hak atas tanah yang sudah dibukukan dalam buku tanah yang bersangkutan sebagaimana yang telah tercantum dalam Pasal 19 ayat (2) huruf c Undang-Undang Pokok Agraria.

Tujuan utama dikeluarkannya Undang-Undang Pokok Agraria yaitu untuk menyatukan dan menyederhanakan hukum pertanahan nasional salah satunya dengan melakukan konversi hak atas tanah yang sesuai dalam ketentuan UndangUndang Pokok Agraria dengan mencabut ketentuan-ketentuan mengenai hak atas tanah dalam Kitab Undang-Undang Hukum Perdata dimana pelaksanaan konversi ini sendiri terdapat batas waktu yang diberikan yaitu selama 20 tahun untuk melakukan pendaftaran konversi. Apabila hak atas tanah barat tidak dilakukan pendaftaran konversi, maka tanah yang bersangkutan statusnya berubah menjadi 
tanah negara ${ }^{4}$ dan otomatis hak atas tanahnya menjadi hapus. Namun dalam hal ini, tanah negara yang dimaksud dapat dilakukan permohonan hak yang mana pemberian haknya merupakan penetapan dari pemerintah. Kewenangan atas pemberian hak tersebut terdapat pada Badan Pertanahan Nasional untuk memberikan hak atas tanah negara kepada perseorangan atau badan hukum. Seseorang yang telah mengajukan permohonan secara tertulis kepada Badan Pertanahan Nasional Kabupaten/Kota setempat yang nantinya akan dilakukan beberapa pengecekan dan penelitian oleh pihak-pihak yang diberi kewenangan yang nantinya akan menghasilkan suatu pendapat apakah pihak yang mengajukan dapat diberikan hak atas tanah yang bersangkutan dengan menyertakan beberapa dokumen tertulis sesuai Pasal 9 dan Pasal 10 Peraturan Menteri Negara Agraria/ Kepala Badan Pertanahan Nasional Nomor 9 Tahun 1999 tentang Tata Cara Pemberian dan Pembatalan Hak Atas Tanah Negara dan Hak Pengelolaan.

Sebagai contoh kasus terdapat sebidang tanah dengan bangunan rumah diatasnya yang dimiliki oleh Bapak Sujono sejak tahun 1960 dimana bangunan rumah tersebut berdiri di atas tanah hak milik bekas hak eigendom nomor 3529 dengan luas $\pm 92 \mathrm{M}^{2}$. Di tahun 2012, Bapak Sujono selaku pemilik hak atas tanah bekas eigendom tersebut berniat untuk menjual tanah beserta bangunan rumah yang berdiri di atasnya kepada Ibu Djamilah. Pembelian tanah beserta bangunan rumah tersebut dilakukan dengan membuat Perjanjian Pengikatan Jual Beli (selanjutnya disebut PPJB) terlebih dahulu di hadapan Notaris setempat. Tahun 2013, Ibu Djamilah selaku pihak pembeli telah mendapatkan akta jual beli nomor 5 tertanggal 4 Februari 2013 yang dikeluarkan oleh Pejabat Pembuat Akta Tanah (selanjutnya disebut PPAT) berniat untuk melakukan balik nama sertipikat dengan menyiapkan dokumen-dokumen yang dibutuhkan, seperti kartu identitas pihak yang berkepentingan, akta jual beli yang dibuat oleh PPAT, kuasa menjual yang dibuat ketika melakukan PPJB, surat bukti tertulis sebagai bentuk kepemilikan dari Ibu Djamilah berupa keterangan yang dibuktikan dengan surat keterangan 2014).[3].

${ }^{4}$ Elza Syarief, Pensertifikatan Tanah Bekas Hak Eigendom (Kepustakaan Populer Gramedia 
dari Kepala Desa Nomor 495/05/02.2006.2013 serta keterangan mengenai data fisik dan data yuridis yang nantinya nantinya akan diserahkan langsung kepada Badan Pertanahan Nasional Kabupaten/Kota setempat untuk dilakukan penelitian dan penetapan batasan-batasan tanah yang nantinya akan diumumkan data fisik dan yuridis serta mengesahkan hasil pengumuman tersebut untuk diterbitkan sertipikat hak atas tanah yang baru.

Dengan diterbitkannya sertipikat tanah yang baru oleh Badan Pertanahan Nasional Kabupaten/Kota inilah membuat tanah beserta bangunan rumah yang berdiri di atas bekas tanah negara hak eigendom tersebut telah mempunyai kepastian hukum yang tetap dan terdapat perlindungan hukum terhadap pemegang hak atas tanah agar memudahkan pembuktian hak atas tanahnya.

\section{Hak Eigendom}

Pengertian dari hak eigendom sendiri sudah tercantum dalam Pasal 570 yaitu hak milik yang kegunaannya atas suatu benda dapat dipunyai dan dinikmati secara leluasa dan bebas asalkan tidak bertentangan dengan peraturan perundangundangan, kecuali jika mengenai pencabutan suatu hak untuk kepentingan umum maka akan diberikan ganti kerugian yang layak dan adil sesuai dengan ketentuan yang telah diatur dalam peraturan perundang-undangan yang sudah berlaku. Dikatakan bahwa pemegang hak eigendom harus dianggap bebas terhadap suatu benda agar dapat menggunakan, memungut hasil, menjual, meminjamkan, menyewakan, menghibahkan atau menggadaikan benda tersebut asalkan tidak bertentangan dengan ketentuan peraturan perundang-undangan yang terkait serta tidak mengganggu hak orang lain dimana dalam hal ini pemilik hak atas tanah eigendom harus memperhatikan kepentingan dari pemilik hak atas tanah lainnya.

Munculnya hak eigendom sendiri dikarenakan adanya teori domein yang telah menciptakan hak atas tanah barat dimana teori domein ini merupakan landasan hukum bagi hukum pertanahan nasional berdasarkan pada hukum tanah pada masa pemerintahan Hindia Belanda. Tujuannya yaitu untuk mempertanggungjawabkan pajak pertanahan hak atas tanahnya serta untuk 
melaksanakan tertibnya administrasi mengenai pertanahan yang sesuai dalam Agrarische Wet 1870 dimana ketentuan tersebut merupakan peraturan perundangundangan yang dibuat oleh Belanda pada tahun 1870 dan diundangkan dalam Staatsblad 1870 Nomor 55 sebagai tambahan pada ketentuan-ketentuan yang baru ${ }^{5}$. Selain itu, Agrarische Wet 1870 juga diatur dengan menggunakan Agrarisch Besluit yang merupakan suatu peraturan pelaksanaan dan diundangkan dalam S. 1870 Nomor 118 yang hanya berlaku di daerah Jawa dan Madura saja.

Mengenai cara perolehan dari hak eigendom sudah tercantum dalam Pasal 584 Kitab Undang-Undang Hukum Perdata, dimana dalam ketentuan tersebut hak eigendom dapat diperoleh dengan cara:

1. Perlekatan, dimana dalam Pasal 588 sampai dengan Pasal 605 Kitab UndangUndang Hukum Perdata sudah diatur mengenai perlekatan dalam suatu kebendaan. Ketentuan tersebut menyatakan mengenai kepemilikan seseorang atas suatu benda;

2. Daluwarsa dapat dikatakan juga sebagai lampaunya waktu atau verjaring, hal ini sudah dijelaskan dalam Pasal 610 Kitab Undang-Undang Hukum Perdata yang mana dalam ketentuan tersebut dikatakan bahwa hak eigendom dapat diperoleh karena lewatnya waktu tertentu serta terpenuhinya syarat-syarat yang telah ditentukan dalam peraturan perundang-undangan;

3. Pewarisan, baik secara peraturan perundang-undang maupun surat wasiat, dimana dalam hal ini pewarisan merupakan salah satu cara untuk memperoleh hak eigendom karena pemberian oleh pewaris kepada ahli waris yang membuat hak serta kewajibannya beralih kepada ahli warisnya;

4. Penunjukan atau penyerahan yang didasari pada suatu peristiwa perdata untuk memindahkan hak atas tanahnya. Ini merupakan suatu perbuatan hukum untuk memindahkan hak pemilik atas tanah eigendom kepada pihak lainnya sesuai dengan kehendaknya sehingga orang tersebut mempunyai hak atas tanah eigendom yang diserahkan. Dalam hal ini dapat dikatakan bahwa peralihan hak atas tanah terjadi ketika telah dilakukannya penyerahan atas hak atas tanah tersebut.

Perkembangan tanah hak eigendom ini tidak terlepas dari campur tangan pemerintah. Hal ini dapat dilihat dari pemerintah yang menciptakan produkproduk hukum sehingga mempengaruhi sistem hukum yang terjadi pada zaman

5 Edwin, ‘Eigendom Sebagai Alat Bukti Yang Kuat Dalam Pembuktian Kepemilikan Tanah Pada Hukum Tanah Indonesia (Analisis Terhadap Putusan Mahkamah Agung Nomor 588 PK/ Pdt./2002)' (Universitas Indonesia 2012). 
tersebut. Salah satunya mengenai kebijakan mengenai pertanahan yang manfaat, pengaturan dan pengelolaannya diatur langsung oleh negara. Hal inilah yang memunculkan berbagai konflik pertanahan sehingga mengganggu kemakmuran bagi rakyat Indonesia. Dengan diterbitkannya Undang-Undang Pokok Agraria membuat keberlakuan hak eigendom maupun hak atas tanah barat lainnya saat ini sudah tidak berlaku dan lebih menegaskan mengenai fungsi sosial atas hak milik yang dimiliki ${ }^{6}$. Selain itu, Undang-Undang Pokok Agraria ini juga lebih menegaskan mengenai status hak atas tanah eigendom dan ketentuan konversi sehingga dapat mensejahterakan dan menjamin kemakmuran rakyat Indonesia sebagaimana yang dimaksud dalam Pasal 33 ayat (3) UUD 1945.

Dalam Peraturan Pemerintah Nomor 24 Tahun 1997, hak eigendom maupun hak atas tanah barat lainnya masih diakui keberadaannya. Hal ini dapat dilihat dalam Pasal 24 ayat (1) yang menyatakan bahwa untuk bukti kepemilikan hak atas tanah barat yang berasal dari kegiatan konversi, Panitia Ajudikasi atau Kepala Badan Pertanahan Nasional Kabupaten/Kota setempat mengumpulkan bukti-bukti kepemilikan pemegang hak atas tanah barat yang berupa bukti tertulis atau jika bukti kepemilikan hak atas tanah tersebut tidak lengkap dapat dilakukan dengan keterangan dari para saksi yang mengetahui kepemilikan atas tanah tersebut. Dalam hal ini, dapat dikatakan bahwa tanah hak eigendom sebenarnya masih diakui namun terdapat beberapa syarat yang harus dipatuhi serta bukti kepemilikan hak eigendom yang dilampiri dengan catatan telah dilakukan konversi menjadi hak milik sesuai ketentuan konversi dan Pasal 3 Peraturan Menteri Agraria Nomor 2 Tahun 1960 tentang Pelaksanaan Ketentuan Undang-Undang Pokok Agraria.

\section{Perbedaan Hak Eigendom Dengan Hak Milik Dalam Undang-Undang Pokok} Agraria

Terdapat perbedaan antara hak eigendom dengan hak milik dalam sistem hukum pertanahan nasional saat ini. Perbedaan tersebut diantaranya yaitu:

6 ibid.[37]. 
1. Tercantum dalam Pasal 570 Kitab Tercantum dalam Pasal 20 UndangUndang-Undang Hukum Perdata. Undang Pokok Agraria.

Tunduk pada Pasal 51 ayat (7) IS

2. yang diatur lebih lanjut dalam Pasal

4 Agrarisch Besluit dan S. 1872 Nomor

Tunduk pada hukum adat.

117 serta $S .1873$ Nomor 38.

Hak kebendaan paling luas yang Hak terkuat dan terpenuh yang dimiliki

3. dikenal dalam hukum kebendaan oleh seseorang atas tanah sehingga bersifat perdata barat. mutlak dan tidak terbatas.

Dasar perolehan hak milik tercantum dalam Pasal 22 Undang-Undang Pokok

Cara perolehan hak eigendom Agraria

tercantum dalam Pasal 584 Kitab 1. Hak milik yang berasal dari hukum Undang-Undang Hukum Perdata

1. Perlekatan;

4. 2. Daluwarsa;

3. Pewarisan;

4. Penunjukan yang didasari pada adat;

2. Hak milik yang berasal dari penetapan pemerintah;

3. Hak milik yang berasal dari tanah negara; suatu peristiwa perdata untuk memindahkan hak atas tanahnya.

4. Hak milik yang berasal dari ketentuan Undang-Undang;

5. Hak milik yang berasal dari peralihan hak.

\section{Konversi}

Beberapa ahli hukum seperti A.P. Parlindungan dan Boedi Harsono memberikan pengertian konversi yang hampir sama. A.P. Parlindungan menyatakan bahwa konversi merupakan suatu pengaturan hak atas tanah yang sudah ada sebelum lahirnya Undang-Undang Pokok Agraria dimana nantinya pengaturan tersebut akan masuk dalam sistem hukum pertanahan yang meliputi suatu kegiatan untuk menyesuaikan hak atas tanah lama menjadi hak atas tanah yang sesuai dalam Undang-Undang Pokok Agraria. ${ }^{7}$ Sedangkan Boedi Harsono menyatakan bahwa konversi merupakan perubahan hak atas tanah yang bersumber dari hukum adat dan hukum barat sudah tidak berlaku lagi dan menjadi satu hak yang baru menurut Undang-Undang Pokok Agraria. ${ }^{8}$

\footnotetext{
7 AP Parlindungan, Pendaftaran Tanah Di Indonesia (Mandar Maju 1990).[1].

8 ibid.[140].
} 
Kegiatan konversi ini merupakan salah satu instrumen dalam memenuhi asas unifikasi hukum pertanahan nasional serta lebih tegasnya hak atas tanah barat maupun hak atas tanah adat yang telah dilakukan konversi agar dapat dilakukan pendaftaran tanah sehingga tidak membuat pemilik hak atas tanah barat merasa dirugikan. ${ }^{9}$ Tujuannya yaitu untuk memberikan kepastian hukum bagi pemegang hak atas tanah yang nantinya akan menghasilkan surat tanda bukti hak sebagai alat pembuktian yang kuat sehingga pemilik hak atas tanah mendapat perlindungan hukum yang tetap. Selain itu, dengan terlaksananya kegiatan pendaftaran konversi ini untuk mewujudkan kemakmuran rakyat yang sesuai dengan Pasal 33 ayat (3) UUD 1945.

Untuk dapat melaksanakan kegiatan konversi ini, terdapat syarat- syarat pendaftaran konversi yang harus dilakukan antara lain: ${ }^{10}$

1. Berkewarganegaraan Indonesia;

2. Fotocopy kartu identitas berupa KTP dan kartu keluarga serta apabila dikuasakan makan menyertakan surat kuasa yang telah dicocokan dengan petugas loket yang berwenang;

3. Memiliki surat tanda bukti kepemilikan berupa alat-alat bukti tertulis seperti peta atau surat ukur;

4. Keterangan para saksi atau pihak yang bersangkutan dan telah diakui kebenarannya oleh Panitia Ajudikasi dan Kepala Badan Pertanahan Nasional Kabupaten/Kota setempat;

5. Sejarah kepemilikan hak atas tanah tersebut harus jelas dan dapat dipertanggungjawabkan dan sedang tidak dalam sengketa;

6. Kepala Badan Pertanahan Nasional Kabupaten/Kota setempat melakukan pencatatan untuk mendaftarkan penegasan konversi hak atas tanah barat dalam buku tanah yang diatur lebih rinci dalam Peraturan Pemerintah Nomor 10 Tahun 1961 yang diubah menjadi Peraturan Pemerintah Nomor 24 Tahun 1997 dan peraturan pelaksanaannya diatur dalam Peraturan Menteri Negara Agraria/Kepala Badan Pertanahan Nasional Nomor 3 Tahun 1997 tentang Ketentuan Pelaksanaan Peraturan Pemerintah Nomor 24 Tahun 1997 tentang Pendaftaran Tanah;

7. Setelah semua persyaratan tersebut terpenuhi, maka Badan Pertanahan Nasional Kabupaten/Kota setempat akan mengeluarkan sertipikat hak milik atas nama pemegang bekas tanah hak atas tanah tersebut.

\footnotetext{
9 Ulfia Hasanah, 'Status Kepemilikan Tanah Hasil Konversi Hak Barat Berdasarkan UndangUndang Nomor 5 Tahun 1960’ (1960) Volume 2 Jurnal Ilmu Hukum 202.

${ }_{10}$ Kementerian Agraria dan Tata Ruang/Badan Pertanahan Nasional, 'Konversi' <https:// www.atrbpn.go.id/Publikasi/Standar-Prosedur/moduleId/126318/controller/Item/action/ Detail?itemName=Konversi,_Pengakuan_dan_Penegasan> accessed 16 July 2020.
} 
Dalam pelaksanaan konversi secara langsung maupun penegasan atau pengakuan hak terhadap pelaksanaan konversi sendiri mempunyai kebijakankebijakan tersendiri untuk melengkapi dokumen yang dibutuhkan dan harus dilengkapi terlebih dahulu. Dokumen-dokumen tersebut diantaranya adalah: ${ }^{11}$

1. Untuk pelaksanaan konversi secara langsung

a. Surat permohonan yang diserahkan kepada Kepala Badan Pertanahan Nasional Kabupaten/Kota setempat;

b. Sertipikat hak atas tanah yang harus disertakan dengan bukti kepemilikan lainnya seperti surat jual, tukar menukar, hibah atau akta waris yang asli dan surat pernyataan tidak terjadi suatu sengketa pada objek kepemilikan;

c. Fotocopy kartu identitas seperti KTP dan kartu keluarga yang berlaku;

d. Fotocopy surat tanda bukti pelunasan Pajak Bumi dan Bangunan (PBB) yang terakhir;

e. Surat kewarganegaraan yang menyatakan bahwa pihak berkepentingan merupakan rakyat Indonesia atau jika pihak yang berkepentingan merupakan warga keturunan, maka harus menyerahkan surat pernyataan ganti nama.

2. Untuk penegasan konversi atau pengakuan hak

a. Surat permohonan yang diserahkan kepada Kepala Badan Pertanahan Nasional Kabupaten/Kota setempat serta menyerahkan bukti penguat berupa surat keterangan dari kelurahan dengan minimal dua saksi atau lebih;

b. Fotocopy kartu identitas seperti KTP dan kartu keluarga yang berlaku;

c. Fotocopy surat tanda bukti pelunasan Pajak Bumi dan Bangunan (PBB) yang terakhir;

d. Surat kewarganegaraan yang menyatakan bahwa pihak berkepentingan merupakan WNI atau jika pihak yang berkepentingan merupakan warga keturunan, maka harus menyerahkan surat pernyataan ganti nama;

e. Apabila terdapat surat ukur atau gambar situasi yang masih berlaku, dapat diserahkan sebagai bukti kepemilikan atas hak atas tanah yang bersangkutan.

Apabila dokumen-dokumen yang diperlukan tersebut lengkap, hal lain yang harus dipersiapkan adalah mengenai biaya atas pengurusan konversi hak atas tanah yang biasanya digunakan sebagai:

a. Biaya pengukuran objek tanah;

b. Biaya pemasukan negara;

11 ibid.[209]. 
c. Biaya pajak untuk melakukan balik nama sertipikat atau yang biasanya dikenal sebagai Bea Perolehan Hak Atas Tanah dan Bangunan;

d. Biaya yang diberikan untuk PPAT.

\section{Hak dan Kewenangan Pemilik Bangunan Yang Berdiri di Atas Tanah Negara} Bekas Hak Eigendom Untuk Melakukan Perjanjian Pengikatan Jual Beli (PPJB)

Pelaksanaan hukum tanah nasional yang didasari dari hukum adat ini tidak lepas dari adanya jual beli tanah yang menimbulkan perbuatan hukum pemindahan hak. ${ }^{12} \mathrm{Hal}$ ini dikarenakan sistem hukum pertanahan di Indonesia konsepsinya berdasarkan pada hukum adat yang syarat sahnya harus memenuhi tiga unsur yaitu asas tunai, riil dan terang. ${ }^{13}$ Menurut Maria S.W. Sumardjono yang dikutip oleh Urip Santoso dalam buku Pendaftaran dan Peralihan Hak Atas Tanah, asas-asas tersebut merupakan sifat jual beli menurut hukum adat yang harus dilakukan. Adapun pengertian dari asas-asas tersebut yaitu: ${ }^{14}$

a. Tunai

Tunai atau yang dapat disebut sebagai contant merupakan suatu harga tanah yang dapat dibayar lunas maupun sebagian yang mana apabila pembayaran harga yang dilakukan bersamaan dengan penyerahan haknya, maka dapat dikatakan bahwa jual beli tersebut dianggap telah selesai. Dalam hal ini, sisa harga yang belum dibayar oleh pihak pembeli dapat dianggap hutang yang harus dibayarkan kepada pihak penjual sebagai bekas pemilik hak atas tanah yang bersangkutan yang mana penyelesaian tersebut dilakukan menurut hukum perjanjian utang piutang. Namun apabila pihak pembeli tersebut tidak membayar sisa harga yang belum dibayar, maka pihak penjual atau pemilik hak atas tanah tersebut tidak dapat membatalkan jual beli hak atas tanah yang bersangkutan.

b. Riil

12 ibid.[29].

13 Maria SW Sumardjono, Kebijakan Pertanahan: Antara Regulasi Dan Implementasi (Penerbit Buku Kompas 2001).[119].

${ }^{14}$ Urip Santoso, Pendaftaran Dan Peralihan Hak Atas Tanah (2019).[361]. 
Riil merupakan suatu tujuan jual beli tanah yang diucapkan oleh pihak pembeli dan harus diikuti dengan perbuatan nyata.

c. Terang

Terang merupakan kegiatan jual beli tanah dimana pelaksanaannya harus dilakukan di hadapan kepala desa yang tidak hanya bertindak sebagai saksi namun juga bertindak sebagai pihak yang bertanggung jawab bahwa kegiatan jual beli yang dilakukan tidak bertentangan dengan hukum yang berlaku. Dengan adanya kepala desa yang bertindak sebagai saksi ini dapat dikatakan bahwa pihak pembeli mendapatkan pengakuan dari masyarakat sekitar sebagai pemilik hak atas tanah yang baru serta perlindungan hukum apabila pihak lain menganggap bahwa jual beli tanah tersebut tidak sah.

Terdapat syarat materiil dan formil yang harus dipenuhi oleh para pihak dalam jual beli tanah dan bangunan. Syarat tersebut diantaranya adalah: ${ }^{15}$

1. Syarat Materiil

a. Para pihak mempunyai kewenangan untuk melakukan jual beli;

b. Jual beli yang dilakukan tertuju pada subjek dan objek yang diperjualbelikan.

2. Syarat Formil

a. Perjanjian jual beli tanah dan bangunan yang ada diatasnya harus dilakukan di hadapan PPAT dan dibuktikan dengan suatu akta yang dibuat di hadapan PPAT sesuai dengan Pasal 37 ayat (1) Peraturan Pemerintah Nomor 24 Tahun 1997.

Mengenai syarat formil perjanjian jual beli yang telah disebutkan tersebut merupakan dasar untuk membuat suatu akta yang harus diakui sebagai alat bukti yang sah. Hal ini karena akta yang dibuat oleh PPAT tersebut mempunyai fungsi dalam penggunaannya, diantaranya adalah: ${ }^{16}$

1. Sebagai alat bukti telah dilakukannya perbuatan hukum;

15 Andy Hartanto, Panduan Lengkap Hukum Praktis: Kepemilikan Tanah (Laksbang Justitia 2015). [151-152].

16 Urip Santoso, Pejabat Pembuat Akta Tanah: Perspektif Regulasi, Wewenang Dan Sifat Akta (Kencana 2017).[126]. 
2. Sebagai dasar untuk dapat melakukan pendaftaran perubahan sertipikat ke Badan Pertanahan Nasional Kabupaten/Kota setempat.

Seperti yang kita ketahui bahwa PPJB yang dibuat oleh PPAT nantinya akan menghasilkan suatu akta jual beli sebagaimana yang telah tercantum dalam Peraturan Pemerintah Nomor 24 Tahun 1997. Dalam hal ini, akta jual beli tersebut dapat memberikan jaminan kepastian hukum kepada pihak pembeli sesuai dengan ketentuan-ketentuan yang terdapat dalam peraturan mengenai pertanahan seperti UUD 1945, Kitab Undang-Undang Hukum Perdata, UndangUndang Pokok Agraria, Undang-Undang Nomor 24 Tahun 1997, dan peraturan perundang-undangan yang berlaku.

Jual beli yang didahului dengan PPJB dalam hal ini mempunyai beberapa ketentuan yang harus diperhatikan. Ketentuan-ketentuan tersebut merupakan syarat yang harus dilakukan sebelum jual beli dilaksanakan. Adapun ketentuanketentuan yang harus diperhatikan antara lain: ${ }^{17}$

1. Objek yang diperjualbelikan harus jelas. Dalam hal ini, objek yang diperhatikan adalah uraian mengenai hak atas tanah seperti luas tanah dan bangunan serta bukti kepemilikan berupa sertipikat;

2. Harga keseluruhan objek jual beli serta proses pembayaran. Pelunasan jual beli dapat dilakukan pada saat akta jual beli telah ditandatangani serta menentukan bagaimana proses pembayaran yang akan dilakukan;

3. Pembayaran pajak yang dilakukan oleh para pihak. Dalam hal ini pembayaran yang dimaksud dapat berupa penegasan biaya untuk pengukuran tanah serta biaya untuk PPAT setempat yang berwenang;

4. Penegasan bahwa objek yang bersangkutan tidak sedang dalam jaminan atau sengketa.

Mengenai hak dan kewenangan pemilik bangunan rumah yang berdiri di atas tanah negara bekas hak eigendom untuk dapat membuat PPJB, terdapat beberapa syarat materiil yang digunakan sebagai syarat sahnya jual beli. Syarat tersebut diantaranya: ${ }^{18}$

1. Pemilik hak yang namanya tercantum dalam bukti kepemilikan mempunyai

17 Dadang Sukandar, 'Yang Perlu Diperhatikan Dalam Perjanjian Pengikatan Jual Beli (PPJB)' $<$ https:/ / www.legalakses.com/yang-perlu-diperhatikan-dalam-perjanjian-pengikatan-jual-beli$\operatorname{ppjb} />$.

18 ibid.[367]. 
hak dan kewenangan untuk menjual hak yang dimilikinya;

2. Pemilik hak harus cakap hukum, apabila pemilik hak tersebut belum cakap hukum, maka dapat diwakili oleh walinya yang sah;

3. Tanah dan/atau bangunan yang diperjualbelikan tidak dalam sengketa;

4. Apabila pemilik hak dalam pengampuan, maka harus diwakili oleh pengampuannya yang mempunyai kuasa;

5. Apabila pihak penjual merupakan penerima kuasa, maka harus menyerahkan surat kuasa notariil sebagai bukti bahwa dia penerima kuasa yang sah;

6. Apabila tanah dan/atau bangunan yang diperjualbelikan merupakan harta bersama, maka harus terdapat persetujuan dari suami atau istri atas jual beli yang dilakukan;

7. Pemilik hak menyerahkan fotocopy KTP dan kartu keluarga yang berlaku, surat nikah, Surat Pemberitahuan Pajak Terutang Pajak Bumi dan Bangunan serta menyerahkan sertipikat hak atas tanah yang diperjualbelikan kepada PPAT setempat untuk membuat PPJB.

Selain itu, dalam pembuatan PPJB yang telah dilakukan juga harus diikuti dengan kuasa menjual oleh pihak pemilik. Hal ini dilakukan apabila pihak pembeli telah melunasi harga jual beli namun belum dapat melakukan balik nama sertipikat sehingga akta jual beli belum dapat dilaksanakan. Namun, apabila persyaratan-persyaratan yang ditentukan telah dipenuhi, maka kuasa menjual tersebut akan ditandatangani oleh pihak pembeli tanpa menghadirkan pemilik bangunan karena sudah memberikan kuasa untuk menjual kepada pihak pembeli.

Ketentuan-ketentuan yang terdapat dalam PPJB ini akan mencantumkan kapan akta jual beli akan dilaksanakan serta mencantumkan kuasa yang diberikan oleh pihak pemilik bangunan kepada pembeli untuk melakukan tanda tangan akta jual beli sehingga pemilik bangunan tidak perlu dihadirkan lagi. Akta jual beli yang dikeluarkan oleh PPAT tersebut merupakan akta bukti tertulis yang sifatnya berupa akta otentik dan merupakan syarat formil dalam pelaksanaan transaksi jual beli sehingga dapat dijadikan sebagai bukti perjanjian jual beli yang nantinya dapat digunakan untuk melakukan pendaftaran pemindahan hak oleh pihak pembeli. ${ }^{19}$ 


\section{Keabsahan dan Perlindungan Hukum Dalam Pemindahan Hak Melalui Perjanjian Jual Beli}

Mengenai pemindahan hak dalam jual beli sendiri telah menyatakan bahwa haknya belum terdapat perubahan meskipun pihak yang pembeli telah membayar lunas maupun objek yang diperjualbelikan telah diserahkan oleh pihak penjual kepada pihak pembeli. Selain itu, pemindahan hak dalam Peraturan Pemerintah Nomor 24 Tahun 1997 sendiri sudah dijelaskan dalam Pasal 37 ayat (1) yang menyatakan bahwa pemindahan hak yang dilakukan melalui jual beli harus dibuktikan dengan suatu akta yang dibuat oleh PPAT sesuai dengan ketentuan yang berlaku. ${ }^{20}$ Kewenangan dari Notaris/PPAT dalam hal ini telah tercantum dalam Pasal 15 Undang-Undang Nomor 2 Tahun 2014 tentang Perubahan Atas Undang-Undang Nomor 30 Tahun 2004 tentang Jabatan Notaris yang mana dalam ketentuan tersebut merupakan dasar hukum Notaris/PPAT untuk membuat suatu akta yang harus diakui sebagai bukti perjanjian jual beli yang sah.

Dengan adanya akta jual beli yang dikeluarkan oleh PPAT dapat digunakan sebagai alas hukum untuk dapat melakukan balik nama sertipikat yang dilakukan dengan cara mendaftarkan proses balik nama ke Kantor Badan Pertanahan Nasional Kabupaten/Kota setempat oleh PPAT dengan menyerahkan dokumendokumen yang terkait seperti:

a. Kartu identitas seperti KTP, kartu keluarga dan surat nikah dari pihak penjual serta pembeli;

b. Fotocopy sertipikat hak atas tanah;

c. Ikatan jual beli;

d. Akta jual beli.

Setelahnya, dapat dikatakan bahwa pemindahan hakyang dilakukan telah terjadi. Hal ini karena telah terjadi penyerahan secara yuridis yang dilakukan di hadapan PPAT karena telah terjadi proses balik nama sertipikat atas nama pihak pembeli. Hal ini yang menjadikan PPJB dapat dikatakan mempunyai keabsahan yang kuat serta perlindungan hukum yang tetap karena didasari oleh suatu bukti berupa akta otentik.

20 ibid.[136]. 


\section{Perolehan Hak Milik Atas Tanah di Atas Tanah Negara Bekas Hak Eigendom}

Tanah negara merupakan tanah yang tidak melekat adanya suatu hak atas tanah. Hal ini dilihat berdasarkan pada Undang-Undang Pokok Agraria yang menganut konsep negara "menguasai" semua bumi, air dan ruang angkasa. Selain itu, ruang lingkup dari tanah negara ini dapat kita lihat dari: ${ }^{21}$

1. Tanah yang diserahkan oleh pemiliknya secara sukarela;

2. Tanah terlantar;

3. Tanah untuk kepentingan umum;

4. Tanah yang tidak terdapat pemegang haknya;

5. Tanah yang jangka waktunya telah berakhir dan tidak diperpanjang lagi.

Tanah negara tersebut dapat diajukan permohonan secara tertulis yang diajukan kepada Menteri melalui Badan Pertanahan Nasional Kabupaten/Kota setempat dengan menyerahkan dokumen-dokumen yang sesuai Pasal 9 dan Pasal 10 Peraturan Menteri Negara Agraria/Kepala Badan Pertanahan Nasional Nomor 9 Tahun 1999 mengenai pemberian hak. Dokumen-dokumen yang dimaksud antara lain:

1. Keterangan pemohon dengan mengajukan identitas yang diperlukan, antara lain:

1) Fotocopy kartu identitas seperti KTP dan kartu keluarga yang berlaku;

2) Surat nikah atau surat keterangan mengenai suami atau istri dan anaknya yang masih menjadi tanggungan;

3) Fotocopy surat tanda bukti kewarganegaraan Indonesia;

2. Keterangan atas tanah yang meliputi data yuridis dan data fisik

a. Data yuridis meliputi dasar penguasaan atas bukti kepemilikan hak atas tanahnya seperti sertipikat, girik, surat bukti pelepasan hak atas tanah, putusan pengadilan, akta PPAT maupun akta pelepasan hak maupun bukti kepemilikan lainnya.

b. Data fisik meliputi surat ukur dan gambar situasi serta surat-surat lainnya yang dianggap perlu. Selain itu, keterangan mengenai jumlah 
bidang, jenis tanahnya apakah tanah pertanian atau non pertanian, status tanahnya apakah tanah hak atas tanah negara serta rencana yang dilakukan atas tanah tersebut.

Apabila permohonan tersebut diterima, maka Kepala Badan Pertanahan Nasional Kabupaten/Kota setempat melakukan pemeriksaan dan penelitian terhadap kelengkapan dan kebenaran dari data fisik dan data yuridis, melakukan pencatatan dan memberikan tanda terima berkas permohonan dalam formulir isian serta memberitahu pemohon yang bersangkutan untuk membayar biaya yang diperlukan sesuai dengan Pasal 12 Peraturan Menteri Negara Agraria/ Kepala Badan Pertanahan Nasional Nomor 9 Tahun 1999.

Selain itu, pemeriksaan mengenai data-data yang diajukan layak diterima atau tidak dapat dilakukan oleh pihak-pihak yang diberikan kewenangan oleh Badan Pertanahan Nasional. Hal tersebut telah tercantum dalam Pasal 13 Peraturan Menteri Negara Agraria/Kepala Badan Pertanahan Nasional Nomor 9 Tahun 1999 yang mana pihak-pihak tersebut diantaranya Kepala Seksi Hak Atas Tanah, Tim Penelitian Tanah dan Panitia Pemeriksa Tanah A yang masing-masing memiliki tugas untuk melakukan pengecekan dan penelitian yang nantinya akan menghasilkan suatu pendapat untuk pertimbangan Kepala Badan Pertanahan Nasional Kabupaten/Kota setempat memberikan keputusan mengenai pemberian hak milik atas tanah negara tersebut dengan menerbitkan Surat Keputusan Pemberian Hak (SKPH). Keputusan yang akan diberikan dapat berupa surat keputusan penerimaan hak atau dapat juga berupa surat keputusan penolakan beserta dengan alasan penolakannya yang disampaikan melalui surat tercatat dan diserahkan kepada pemohon yang berhak.

Apabila permohonan hak tersebut diberikan, maka Kepala Badan Pertanahan Nasional Kabupaten/Kota setempat akan menyampaikan berkas permohonan beserta pendapat dan pertimbangan kepada Kantor Wilayah Badan Pertanahan Nasional yang nantinya akan melakukan pencatatan, pemeriksaan dan penelitian apakah data-data yang diberikan telah lengkap dan sesuai. Setelah itu, Kepala Kantor Wilayah Badan Pertanahan Nasional yang akan memberikan hak milik 
tersebut menyerahkan berkas permohonan yang telah diteliti beserta dengan pendapat dan pertimbangannya kepada Menteri yang nantinya akan menerbitkan surat keputusan pemberian atau penolakan hak milik atas tanah negara yang dimohonkan. Pemberian hak atas tanah ini dilakukan secara umum oleh Kepala Badan Pertanahan Nasional yang telah dijelaskan dalam dalam Pasal 12 Peraturan Kepala Badan Pertanahan Nasional Nomor 2 Tahun 2013 tentang Pelimpahan Kewenangan Pemberian Hak Atas Tanah dan Kegiatan Pendaftaran Tanah.

Kewajiban bagi pihak yang telah diberikan hak atas tanah negara sudah tercantum dalam Pasal 103 ayat (1) Peraturan Menteri Negara Agraria/Kepala Badan Pertanahan Nasional Nomor 9 Tahun 1999 yang diantaranya:

1. Membayar Bea Perolehan Hak Atas Tanah (BPHTB);

2. Membayar uang pemasukan kepada negara;

3. Menjaga dan merawat dengan baik batas-batas tanah yang diberikan;

4. Menggunakan dan memanfaatkan dengan baik tanah sesuai dengan kepentingannya dan sesuai dengan lingkungannya;

5. Mencegah kerusakan dan hilangnya kesuburan tanah;

6. Melakukan kewajiban-kewajiban yang tercantum dalam sertipikat hak atas tanah.

\section{Kesimpulan}

Pemilik bangunan mempunyai hak serta wewenang untuk dapat melakukan PPJB dengan pihak lain dikarenakan sistem hukum pertanahan Indonesia yang salah satunya Undang-Undang Pokok Agraria ini bersumber dari hukum adat serta menganut asas pemisahan horisontal. Mengenai tata cara perolehan hak milik atas tanah di atas tanah negara bekas hak eigendom dalam hal ini dapat dilakukan dengan cara mengajukan permohonan secara tertulis kepada Badan Pertanahan Nasional sesuai dengan ketentuan-ketentuan yang terdapat pada Peraturan Menteri Negara Agraria/Kepala Badan Pertanahan Nasional Nomor 9 Tahun 1999.

Saran yang dapat diambil dari pembahasan di atas yaitu seharusnya setiap PPJB yang dilakukan harus ditindaklanjuti dengan suatu akta jual beli yang bersifat sebagai akta otentik dan merupakan salah satu syarat formil dalam pelaksanaan 
transaksi jual beli. Selain itu, proses perolehan hak milik atas tanah di atas tanah negara bekas hak eigendom yang diajukan kepada Badan Pertanahan Nasional seharusnya dapat dibantu oleh PPAT.

\section{Daftar Bacaan}

\section{Buku}

A.P. Parlindungan, Pendaftaran Tanah Di Indonesia (Mandar Maju 1990).

Andy Hartanto, Panduan Lengkap Hukum Praktis: Kepemilikan Tanah (Laksbang Justitia 2015).

Boedi Harsono, Hukum Agraria Indonesia: Sejarah Pembentukan Undang-Undang Pokok Agraria, Isi Dan Pelaksanaannya (Djambatan 2007).

Elza Syarief, Pensertifikatan Tanah Bekas Hak Eigendom (Kepustakaan Populer Gramedia (KPG) 2014).

Maria S.W. Sumardjono, Kebijakan Pertanahan: Antara Regulasi Dan Implementasi (Penerbit Buku Kompas 2007).

Urip Santoso, Hukum Agraria: Kajian Komprehensif (Kencana 2012).

- - , Pendaftaran Dan Peralihan Hak Atas Tanah (Kencana 2010).

- -, Pejabat Pembuat Akta Tanah: Perspektif Regulasi, Wewenang dan Sifat Akta (Kencana 2017).

\section{Jurnal}

Andhi Mahligai, 'Penerapan Alternatif Penyelesaian Sengketa dan Konflik Pertanahan Melalui Mediasi Untuk Mewujudkan Kepastian Hukum Di Bidang Pertanahan Nasional Republik Indonesia', Tesis (Magister Ilmu Hukum Universitas Atma Jaya Yogyakarta 2013).

Edwin, 'Eigendom Sebagai Alat Bukti Yang Kuat Dalam Pembuktian Kepemilikan Tanah Pada Hukum Tanah Indonesia (Analisis Terhadap Putusan Mahkamah Agung Nomor 588 PK/Pdt./ 2002)', Tesis (Magister Kenotariatan Universitas Indonesia 2012).

Ulfia Hasanah, 'Status Kepemilikan Tanah Hasil Konversi Hak Barat Berdasarkan Undang-Undang Nomor 5 Tahun 1960', (2012) Jurnal Ilmu Hukum. 


\section{Laman}

Kementerian Agraria dan Tata Ruang/Badan Pertanahan Nasional, 'Konversi', <https://www.atrbpn.go.id/Publikasi/Standar-Prosedur/ moduleId/126318/controller/Item/action/Detail?itemName=Konversi,_ Pengakuan_dan_Penegasan>, diakses pada tanggal 15 Juli 2020, pukul 19.16 WIB.

Dadang Sukandar, 'Yang Perlu Diperhatikan Dalam Perjanjian Pengikatan Jual Beli (PPJB)'. <https://www.legalakses.com/yang-perlu-diperhatikandalam-perjanjian-pengikatan-jual-beli-ppjb/>, diakses pada tanggal 21 Mei 2020, pukul 20.38 WIB.

\section{Perundang-undangan}

Undang-Undang Dasar Negara Republik Indonesia Tahun 1945.

Kitab Undang-Undang Hukum Perdata (Burgerlijk Wetboek, Staatsblad 1847 Nomor 23).

Undang-Undang Nomor 5 Tahun 1960 tentang Peraturan Dasar Pokok-Pokok Agraria (Lembaran Negara Republik Indonesia Tahun 1960 Nomor 104, Tambahan Lembaran Negara Republik Indonesia Nomor 2043).

Undang-Undang Nomor 2 Tahun 2014 tentang Perubahan Atas Undang-Undang Nomor 30 Tahun 2004 tentang Jabatan Notaris (Lembaran Negara Republik Indonesia Tahun 20014 Nomor 3, Tambahan Lembaran Negara Republik Indonesia Nomor 5491.

Peraturan Pemerintah Nomor 24 Tahun 1997 tentang Pendaftaran Tanah (Lembaran Negara Republik Indonesia Tahun 1997 Nomor 59, Tambahan Lembaran Negara Republik Indonesia Nomor 3696).

Keputusan Presiden Nomor 32 Tahun 1979 tentang Pokok-Pokok Kebijaksanaan Dalam Rangka Pemberian Hak Baru Atas Tanah Asal Konversi Hak-Hak Barat.

Peraturan Menteri Agraria Nomor 2 Tahun 1960 tentang Pelaksanaan Ketentuan Undang-Undang Pokok Agraria (Tambahan Lembaran Negara Republik Indonesia Nomor 2086).

Peraturan Menteri Negara Agraria/Kepala Badan Pertanahan Nasional Nomor 3 Tahun 1997 tentang Ketentuan Pelaksanaan Peraturan Pemerintah Nomor 24 Tahun 1997 tentang Pendaftaran Tanah. 
Peraturan Menteri Negara Agraria/Kepala Badan Pertanahan Nasional Nomor 9 Tahun 1999 tentang Tata Cara Pemberian dan Pembatalan Hak Atas Tanah Negara dan Hak Pengelolaan.

Peraturan Kepala Badan Pertanahan Nasional Nomor 2 Tahun 2013 tentang Pelimpahan Kewenangan Pemberian Hak Atas Tanah dan Kegiatan Pendaftaran Tanah (Berita Negara Republik Indonesia Tahun 2013).

How to cite: Diyah Retno Habiba, 'Perolehan Hak Milik yang Berasal Dari Perjanjian Pengikatan Jual Beli (PPJB) Terhadap Bangunan yang Berdiri Di Atas Tanah Negara Bekas Hak Eigendom' (2020) Vol. 3 No. 3 Notaire. 
348 | Diyah Retno: Perolehan Hak Milik...

--Halaman ini sengaja dikosongkan-- 